HACK Márta

DOI: 10.15170/DiKE.2017.01.01.02

főiskolai docens, tanszékvezető

Szent Pál Akadémia Ókori nyelvek Tanszék

\title{
Az európai jogi kultúra zsidó-keresztény gyökerei
}

\section{Judeo-Christian Roots of the European Legal Culture}

This article deals with the Judeo-Christian roots of the European legal culture. The Torah or mosaic Law contains the basic principles of individual human rights, equality before the Law, rule of Law. The Ten Commandments as universal ethical norm is not only a catalogue of moral obligations, but it is a source of human liberties. The analysis of the Decalogue shows the toraic regulation that shaped our conceptions of the value of human life, family, education, property, dignity, privacy, judiciary system and good governance. This study makes an attempt to connect the Old Testament legislation and the western society through the reception of the New Testament in the European culture, to show how relevant are the toraic values still today.

Keywords: biblical anthropology, biblical principles of jurisdiction, inalienable buman rights, public good, rule of law, Ten Commandments, universal ethical norm

\section{Bevezetés}

Jelen írás arra keresi a választ, milyen bibliai elvek alakították az európai jogi kultúrát. Az európai kultúra három fő forrása a görög bölcselet, a római jog és a zsidó-keresztény vallásetika. A Biblia kétségkívül az európai kultúra egyik alappillére, melynek egyetemes erkölcsi elvei kimutathatóan beépültek a jogról és igazságosságról alkotott felfogásunkba. Elsőként a legalapvetőbb jogokat szeretném kimutatni a Tórában, majd a Tízparancsolatot vizsgálom abból a szempontból, miként hatnak annak máig érvényes alapelvei a törvényességrôl alkotott képünkre, végül kitérek az újszövetségi törvényértelmezésre és államfelfogásra. A Tóra Mózes törvényét és tágabb értelemben Mózes öt könyvét jelöli, amelyben a jogi korpusz helyet foglal, a történeti, elbeszélő részeken belül. Szűkebb értelemben a Tórán csak a törvényszövegeket értjük. A Tóra szó törvényt és tanítást jelent. Mózes öt könyve azonban nemcsak törvénykönyv, hanem történelemkönyv is. Mózes első könyve a világ teremtésétől kezdődő, az emberiség őstörténetét is felölelő narratívába ágyazza Izrael néppé válásának folyamatát, és leírja ennek központi eseményét, Isten és Izrael szövetségkötését, amelynek során a törvény kinyilatkoztatására került sor. A tórai alapértékek alatt egyfelől az ember teremtésétől fogva adott ősi, elidegeníthetetlen jogokat, másfelől a törvényadáskor kijelentett parancsolatok által védett értékeket értjük. A tórai alapértékeket a szövegforrások bemutatásával és magyarázatával kívánom feltárni. 


\section{A Biblia emberképe}

Az európai jogi gondolkozást nagymértékben meghatározza a Szentírás emberképe. „A Biblia szerint az. ember alapvetó jogai egyidösek az emberiséggel, mivel azok eleve hozzátapadnak az emberhez, tehát nem történelmileg keletkętek. Legalapvetöbb jogaink Istentöl származnak, azok ösi, elidegenithetetlen örökeségünket képezilk. (...) Ha szemügyre vesszük öket, rögtön szembeötlik, bogy a történelem folyamán sz̨inte mindegyiküuk állami törvényekkeel is megerösitést nyert." ${ }^{1}$ A Bibliából kitúnik, hogy az ember kivételes helyet foglal el az Isten által teremtett világmindenségben. Létezésének értelmes célja van. Az ember eredetét tekintve Isten elhatározásából és saját képmására teremtett lény, aki értelemmel, szabadsággal és kormányzati tekintéllyel van felruházva. ${ }^{2}$ Származásából és uralomra feljogosított mivoltából fakadóan tisztességre és megbecsülésre méltó. Az emberi méltóság legtömörebb megfogalmazása a 8. Zsoltárban olvasható, amely a bibliai humanizmus manifesztuma. „Micsoda az ember mondom hogy megemlékezel róla? És az embernek fia, hogy gondod van reá? Hiszen kevéssel tetted öt kisebbé az. Istennél, és dicsöséggel és tisz̨tességgel megkoronáżtad öt! Úrrá tetted öt kęzeid munkáin, mindent lábai alá vetettél.”3

Az ember eredendő, elidegeníthetetlen méltósága teremtésének módjából és céljából fakad. Az embert minden más élőlénytől megkülönbözteti teremtésének módja. Az Istennel való hasonlóság hordozója és letéteményese az emberbe belélehelt szellem (az „élet lehellete”), amit a Teremtő közvetlenül lehelt az ember orrába, és amitől az ember élő és gondolkodó lény lett. „És formálta vala az Úr Isten az embert a földnek porából, és lehellett vala az ô orrába életnek. lehelletét. Így lön az. ember élo lélekkeé."4 Az individuum értékére mutat az a tény, hogy Isten először egy egyént teremtett, és miután látta, hogy „nem jó az embernek egyedül’, társául megalkotta a nőt, mint „segitótársat, bozఇá illót." "5 Ennek fényében az ember jóléte érdekében cselekvő Teremtönek köszönhető az első emberi közösség, a házasság létrejötte. E kötelék kifejeződése, hogy az ember „ragaszkodik feleségéhez: és lesznek egy testte'. ${ }^{6}$

A házasság ezen egyszerű definíciója szerint az a nemek különbözőségén és a felek hűségén alapul. A házasság intézménye, mint férfi és nő egymás iránti elkötelezettsége „régebbi a társadalmaknál, államoknál, hiszen az elsô emberpárra vezethetō vissza." 7 Amennyiben a természet rendjéből jogi következtetést lehet levonni, a nemek különbözőségén alapuló házasság jogi védelme nem társadalmi konstrukción, hanem természeti törvény felismerésén nyugszik. Ahol a bibliai szöveg két nemről, a férfiról és a nőről tesz említést, ugyanott hangsúlyozza, hogy az ember Isten képmására lett teremtve, következésképpen mindkét nem tagjai egyenrangúak: egyformán8 rendelkeznek mind az istenképűség belső tartalmával, mind az abból fakadó méltósággal. „Teremté tehát az. Isten az embert az ő képére, Isten képére teremté öt: férfiúvá és asszonnyá teremté öket." "Teremtésének

\footnotetext{
${ }^{1}$ MÉSZÁros, Bibliai államelmélet 19.

2 CONNER, Foundations 123-130.

${ }^{3}$ Zsoltárok 8:5-7

41 Mózes 2:7

51 Mózes 2:18

61 Mózes 2:24b

${ }^{7}$ MÉSZÁROS, Bibliai államelmélet 20.

${ }^{8}$ Apostolok cselekedetei 17:26

91 Mózes 1:27
} 
céljait tekintve minden más élőlény közül kiemeli az embert, hogy a Föld benépesítésére, és a természet fölötti uralomra kapott felhatalmazást. „És megáldá Isten ökeet, és monda nékik Isten: Szaporodjatok és sokasodjatok, és töltsétek be a földet és hajtsátok birodalmatok alá; és uralkodjatok a tenger halain, az ég madarain, és a földön csús zó-mászó mindenféle állatokon. És monda Isten: Imé néktek adok minden magho ớ füvet az egész föld sæínén, és minden fát, amelyen maghozó gyümölcs van; az legyen néktetek eledelül."10 Az első emberpár a házasság és a család intézményének szentesítésével együtt tulajdonjogot kapott mind lakóhelyét illetően, mind pedig a természet adta javak birtokba vételét illetően. Az ember javára cselekvő Teremtő tulajdont és felelősséget bízott az emberre. „És vevé az Úr Isten az, embert, és belyezteté ôt az. Éden kertjébe, hogy mivelje és örizze azt." "A tulajdon intézménye az isteni jog szerint egyértelmüen magántulajdon: az egyénekhez, családokhoz, kötódik, az ö boldogulásukat szolgálja."12 Az édeni viszonyokból levezethető a családalapításhoz, a magántulajdonhoz, sőt az egészséges környezethez való jog is. ${ }^{13}$

\section{A törvény, a bün és az ítélet összefüggése}

A Biblia olyan emberképet tár elénk, ami szerint az emberi nemet az állatvilágtól megkülönbözteti, hogy Isten képmására teremtett, értelemmel és széleskörű cselekvési szabadsággal felruházott lény, aki szabad akarattal rendelkezik, épp ezért erkölcsi lény is. ${ }^{14}$ Szabadsága korlátait az a törvény határozta meg, aminek forrása maga Isten, ezért tetteiért neki tartozik felelősséggel. Az embernek adott első törvény egyetlen negatív parancsot tartalmazott, aminek megszegéséhez szankció kapcsolódott. Már az őstörténetben egyértelmű az összefüggés a törvény, a bűn és a bűnhődés között. A törvény áthágása a bűn, a bűn következménye a halál. A kert minden fájára és azok gyümölcseire vonatkozó széleskörű engedély mellett egyetlen tilalom figyelmeztetett a szabad cselekvés korlátjára. „De a jó és gonosz. tudásának fájáról, arról ne egyél; mert amely napon ejéndel arról, bizony meghalsæ:" 15

A törvény volt hivatott arra, hogy felszínre hozza az ember döntési felelősségének súlyát, az egyén morális mivoltát. A törvény megszegésével együtt járó a fenyegetés az élet elveszítésére egyúttal rávilágít a törvény céljára: megtartása az ember számára jó. A történetben az a mély gondolat sejlik fel, hogy az élet fája mindaddig hozzáférhetô, ameddig az emberiség a törvényt megtartja. A büntetési tétel az elvesztett élet értékét hozza felszínre. A jó törvények mindenkori kritériuma, hogy végső fokon az életet pártolja-e, az ember földi boldogulását célozza-e vagy sem, a büntetés arányos-e az okozott kár mértékével.

\footnotetext{
101 Mózes 1:28-29

111 Mózes 2:15

12 MÉSZÁros, Bibliai államelmélet 20.

13 MÉSZÁros, Bibliai államelmélet 20.

${ }^{14}$ CONNER, Foundations 124.

151 Mózes 2:17
} 


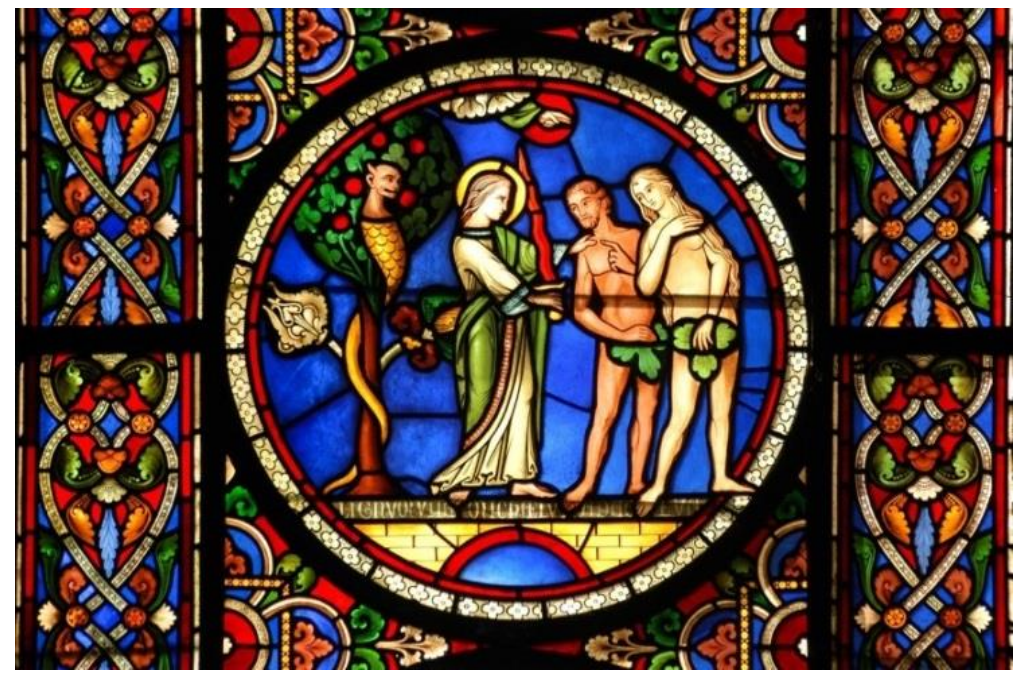

Ádám és leszármazottai a tilalom megszegését követően szükségképpen meg kellett ismerjék a bűn és a büntetés összefüggését, a szuverén Törvényhozó jogos büntető-igényét és azt, ahogy az gazságosság kívánalma szerint a törvénynek érvényt szerez.

1.kép: Angyal lángpallossal az igazságszolgáltatás jelképe

A paradicsomból való kiűzetés narratívája az emberi reakciókon keresztül ábrázolja, ahogyan a bűnös lelkiállapota megváltozik már azt megelőzően, hogy Isten kihirdette volna az ítéletet. A bűntudatot a bűn létére vezeti vissza, nem külső kondicionálásra, ami által tudatosult a törvénysértô magatartás. A lelkiismeret törvénye, mint szubjektív, a priori törvény akkor is vád alá helyezi az egyént, ha nincs jelen külső vádhatóság, és nincs előzetes ismerete, tapasztalata az ítéletről. A jó és rossz tudásának fája azért volt tilalmas, mert az ártatlanoknak a jó és rossz közötti határ ismeretlen: nem tudjuk, mi a rossz, amíg el nem követjük. A bủntudat a határsértést jelzi. A lelkiismeret törvényéből, mint univerzális emberi tapasztalatból természetjogi következtetést lehet levonni. A törvény és az igazságosság, a bűn és büntetés fogalma, a jogtudat eszerint egyidős az emberiséggel. A bűn és a büntetés definíciója az Újszövetségben lényegében változatlan maradt, „a bün pedig a törvénytelenség," "16 „a bün zsoldja halál’17 A vádlott meghallgatása szintén része az igazságos ítélethozatalnak. A Tórában a bűnbeesés történetében, Ádám kihallgatásánál találkozunk először vele. Káin esetében ugyancsak történt meghallgatás. A tisztességes eljárásra és az emberi élet védelmére a Tízparancsolat VI. és IX. cikkelye magyarázatánál térek ki bővebben.

\section{A Tóra alapértékei a Tízparancsolat tükrében}

\subsection{A Tóra, mint alapszerződés}

A törvényadás eseménye Izraelt a népek között sajátos egyedülálló jogi státusba helyezte. A szövetségkötés Mózes közvetítésével történt meg a Mindenható és választott népe, Izrael között, melyet Egyiptomból vezetett ki, hogy Kánaánban új hazát biztosítson neki az Ábrahámnak adott ígérete szerint. A mindkét félre kötelező érvénnyel bíró írásos szerződés létrejötte és a szerződést megelőző társadalmi közmegegyezés kialakítása minden bizonnyal mérföldkő a jog történelmében, messze túlmutat a kor szokásjogán vagy annak irodalmi formába öntésén ${ }^{18}$. Paul Johnson kiemeli a

\footnotetext{
161 János 3:4b

${ }^{17}$ Róma 6:23a

${ }^{18}$ H. Tadmor úgy véli, az ókori törvénykönyvek nem a mai értelemben vett törvénykönyvek, bár kódexnek hívják pl. Hammurapi kódexét, nem annyira a mindennapos döntéseket irányító eljárásjogi eszközök voltak, mint inkább a korabeli bírói gyakorlat sűrítménye, a helyi szokás szerinti döntések irodalmi formába öntése. Lásd BEN SASSON, History 118119.
} 
törvényadás társadalomformáló szerepét, mellyel az izraeliták újfajta társadalmat teremtettek: „, $A$ mózesi kódexben mindenféle kiváltság benne foglaltatik, de a lényeges kérdések tekintetében nem tesz. különbséget a bivök egyes csoportjai között. Valamennyiüknek része van a sqövetség elfogadásában; ez pedig népi, sốt demokratikus döntés volt. (...) Philo a rendszert < demokráciának > nevezte, amelyet úgy jellemzett, mint $<$ a legtörvénytisztelőbb és legjobb alkotmányt $>$."19

Tízparancsolat Izrael néppé válásának központi jogi dokumentuma, mely a szigorú erkölcsi monoteizmus talaján áll. Minden más mózesi törvény levezethető a dekalógusból, az esetjog nem más, mint ennek a tíz alapvető parancsolatnak a gyakorlati kifejtése és alkalmazása. Az esetjog kodifikációja a dekalógusban foglalt törvények elhangzását követi. Három törvénytípus különíthető el a Tórában: ezek részint erkölcsi parancsok (egyetemes etikai elvek); részint ceremoniális szabályok (speciálisan Izrael népére, földjére és istentiszteletére vonatkozó parancsok, melyek sajátos céllal elkülönítik más népektől, helyhez és néphez kötöttek); valamint polgári törvények (melyek a közjót szolgálják, elvei bárhol átültethetőek a gyakorlatba). A Tízparancsolat az első kategóriába tartozik. A két kőtáblának megfelelően ${ }^{20}$ két kategóriába sorolhatjuk a törvényeket: az elsô négy parancsolat Isten és ember viszonyát szabályozza, a további parancsolatok az ember és ember közötti viszonyt.

„És szólá Isten mindezeket az, igéket, mondván: Én, az Úr, vagyok a te Istened, aki kihoztalak téged Egyiptomnak. földéról, a szolgálat bázából.

I. Ne legyenek néked idegen isteneid én elöttem.

II. Ne csinálj magadnak faragott képet, és semmi hasonlót azokhoz, amelyek fenn az égben, vagy amelyek alant a földön, vagy amelyek a vižekben a föld alatt vannak. Ne imádd és ne tiszteld azokat; mert én, az Úr a te Istened, féltön-szeretố Isten vagyok, aki megbüntetem az atyák vétkét a fiakban, harmad és negyedĩiglen, akik engem gyülölnek. De irgalmasságot cselekszem ezzeríziglen azokekal, akik engem szeretnek, és az én parancsolatimat megtartják.

III. Az Úmak a te Istenednek nevét biába fel ne vedd; mert nem hagyja aẓt az Úr büntetés nélkeül, aki az ô nevét biába felveszi.

IV. Megemlékezzél a szombatnapról, hogy megszenteljed azt. Hat napon át munkálkodjál, és végezd minden dolgodat; De a hetedik nap az Úrnak a te Istenednek szombatja: semmi dolgot se tégy azon se magad, se fiad, se leányod, se szolgád, se szolgálóleányod, se barmod, se jövevényed, aki a te kapuidon belöl van; Mert hat napon teremté az Úr az eget és a földet, a tengert és mindent, ami azokban van, a hetedik napon pedig megnyugovék. Azért megáldá az Úr a szombat napját, és megszentelé azt.

$V$. Tisžteld atyádat és anyádat, hogy hosszú ideig élj azon a földön, amelyet az Úr a te Istened ád te néked.

VI. Ne ölj.

VII. Ne paráználkodjál.

VIII. Ne lopj.

IX. Ne tégy a te felebarátod ellen hamis tanúbironyságot.

X. Ne kivánd a te felebarátodnak házát. Ne kivánd a te felebarátodnak feleségét, se szolgáját, se szolgálóleányát, se ökrét, se szamarát, és semmit, ami a te felebarátodé."21

${ }^{19}$ JOHNSON, A zsidók története 58.

205 Mózes 10:3

212 Mózes 20:1-17; másik változata: 5 Mózes 5:6-21. 


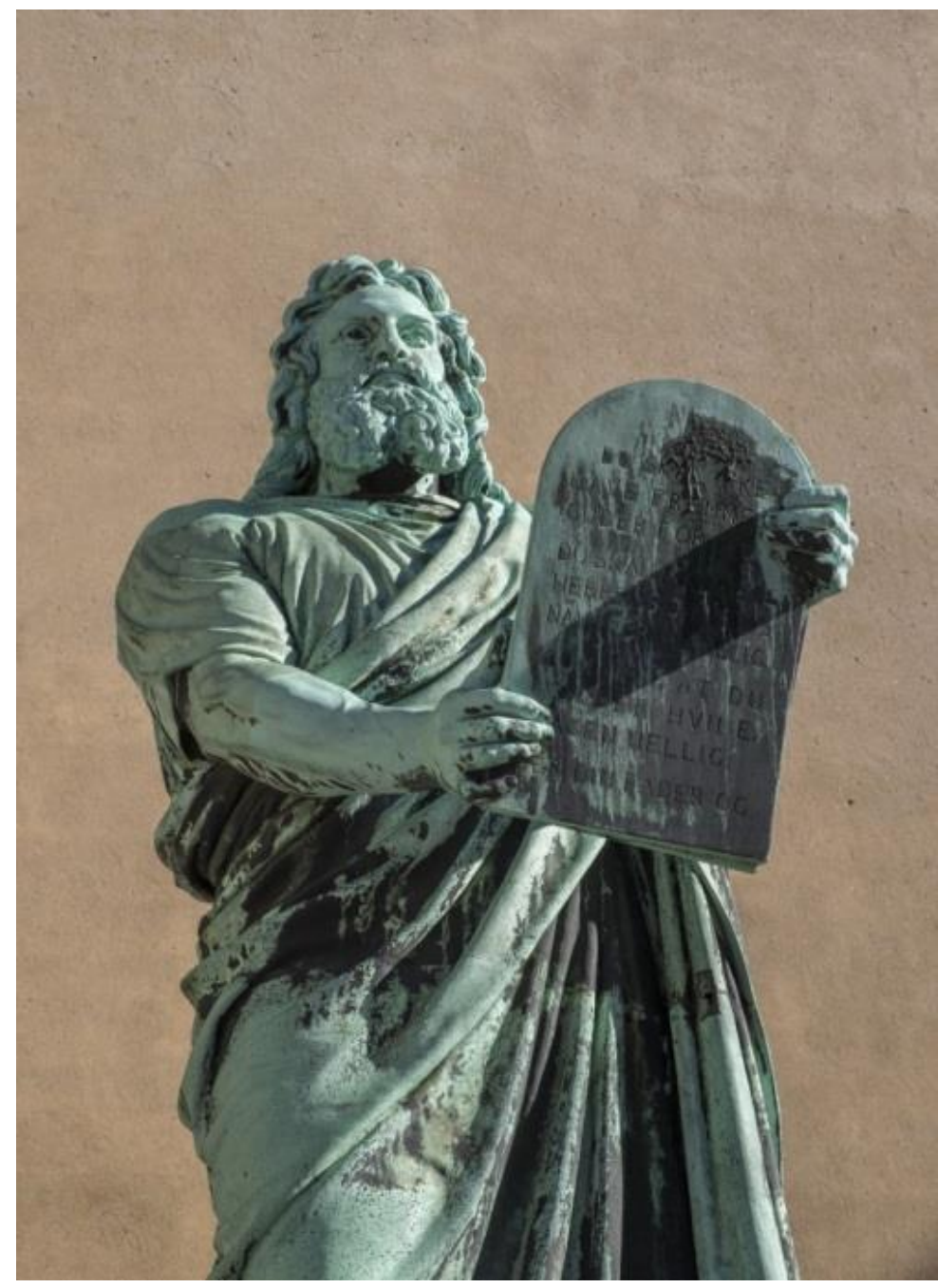

„A sqóban forgó erkölcsi szabályok némelyike más ókori közel-keleti civilizációkban is elterjedt; [...] Am ami az. Istennel és az emberrel szembeni helyes magatartás átfogó summáját illeti, amelyet egy egész népnek. felkinálnak, a nép pedig elfogadja és a szivébe vési, elmondható, bogy az. Tizparancsolatnak az egész. ókorban még csak halvány mása sem létezik." - írja Paul Johnson történész. Mint hangsúlyozza, a mózesi szövetség „az ösi közel-keleti szerzoódések, például a hettiták szerzódéseinek mintáját követi. Van egy történelmi bevezetése, amely kitüri a célt, ezt követi a vállalkozás természetének, az. isteni tanúknak, az áldásoknak és az. átkoknak megnevezése, majd a szöveg és végül a szöveget tartalmazó táblák lelöbelye. A mózesi szövetség azonban a maga nemében páratlan, mivel benne nem államok kötnek egyezséget, hanem Isten és a nép.".22

2. kép: Mózes a kőtáblákkal. Újfajta társadalmat teremtett

A Törvényadó ugyanakkor személyesen, egyes szám második személyben szólítja meg hallgatóját, ezzel szinte önmaga elé állítja az embert, mint egyént. Mivel a törvény isteni eredetû, mindenkire nézve kötelező, és ezért e törvény előtt - ahogyan Isten előtt - minden ember egyenlő.

A dekalógus a teljes törvényszöveg kiindulópontja és magva. Bevezetőből, történeti visszatekintésből és tíz valláserkölcsi parancsolatból áll, melyet részletes esetjogi magyarázat követ. Mózes ötödik könyvében a törvénykönyv záradéka áldásokat ígér a törvény megtartóinak, és átkokat helyez kilátásba a szövetségszegőknek, majd végül Isten tanúul hívja az eget és a földet. A dekalógus szövegét abból a szempontból fogom elemezni, hogy milyen jogi elvek következnek az egyes részekből, hogyan befolyásolják a törvények funkciójáról alkotott képünket.

\subsection{Preambulum}

„És szólá Isten mindezeket az, igéket, mondván: Én, az Úr, vagyok a te Istened, aki kihoztalak téged Egyiptomnak. földéról, a szolgálat házából."

22 JOHNSON, A zsidók története 51. 
Az ókori keleti alapszerződések mintájára a törvény történelmi bevezetéssel kezdődik. A közös vállalkozás szövegének preambuluma a szövetséget kezdeményező fél bemutatkozását tartalmazza: először nevét, majd történelmi tettét említi, ami az Exodus volt. A szerződés az egész népre vonatkozik, azaz kollektív, a megszólítás viszont egyes szám második személyú, azaz személy szerint a nép minden tagjának szól. A bevezető szakaszban megfogalmazott gondolat, hogy az emberi szabadság védendő érték. A szabadság az elnyomás ellentéte.

A zsarnokság Egyiptomban Jákob leszármazottai elleni etnikai tisztogatással felérő demográfiai háborúval, kezdődött, kényszermunkával folytatódott és a héberek istentiszteletének állami meggátlásával csúcsosodott ki. A transzcendens boldogság keresése alapvető jog. A szabadság, egyének és népek vonatkozásában egyaránt Isten ajándéka, hogy ezt a jogát minden ember gyakorolhassa.

\subsection{Az egyetlen Isten tisztelete}

„I. Ne legyenek néked idegen isteneid én elöttem. II. Ne csinálj magadnak faragott képet, és semmi hasonlót azokhoz, amelyek, fenn az égben, vagy amelyek alant a földön, vagy amelyek a vizekben a föld alatt vannak. Ne imádd és ne tiszteld azokat; mert én, az Úr a te Istened, féltön-szeretö Isten vagyok, aki megbüntetem az atyák vétkét a fiakban, harmad és negyedíriglen, akik. engem gyülölnek. De irgalmasságot cselekszem ezeríiglen azok.kal, akike engem szeretnek, és az én parancsolatimat megtartják."

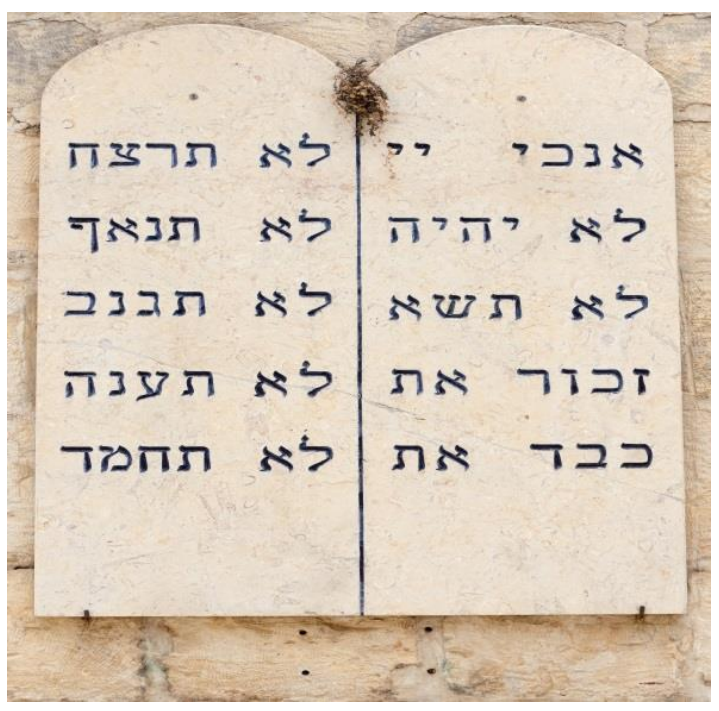

Az első két parancsolatban megfogalmazódik, hogy Isten szuverén törvényadó és legfőbb bíró, aki él a büntetés és megjutalmazás eszközével. A Törvény záradékában megerōsíti, hogy „Enyém a bosszuállás és megfizetés.” 23 A Tóra a szigorú erkölcsi monoteizmus talaján áll és mindenféle istenábrázolást tilt. A benne foglalt törvényeket Isten kinyilatkoztatott akaratának tekinti, amit Izraellel megismertetett történelmi térben és időben, akinek ezáltal morális kötelezettsége keletkezett ennek védelmére és megőrzésére a korokon át, a jellemzően politeista környezetben.

3. kép: Ezek az utcát díszítő kőtáblák a Tízparancsolatra emlékeztetnek Jeruzsálemben

Az idegen istenségek figuratív ábrázolásainak megsemmisítése része volt Izrael küldetésének, és elsősorban önvédelemként szolgált, nehogy a szinkretizmussal kultúraváltás történjen, a kultúraváltással pedig a vallás megváltoztatása. ${ }^{24}$ Az idegen kultuszok bevezetésével

\footnotetext{
235 Mózes 32:35a

242 Mózes 34:12-17
} 
szembeni ellenállásra vonatkozó alábbi törvény érdekes módon nyomozóhatóság felállítását szorgalmazza az új hazában: „Ha valamelyikben a te városaid közül, amelyeket az Úr, a te Istened ád néked, hogy ott lakjál, eat hallod mondani: Emberek jöttek ki közülled, istentelenségnek fiai, és elforditják városuk. lakosait, mondván: Nosza, menjünk és tiszteljünk idegen isteneket, akiket nem ismertetek: Akkor keress, kutass és szorgalmatosan tudakozódjál, és ha igaz, és bizonyos a dolog, és megtörtént az efféle útálatosság közötted: Hányd kard élére annak a városnak lakosait; áldozd fel azt mindenestól, ami benne van; a barmát is kard élére hányd."25 Az információszerzésre, majd ezt követően az értesülések ellenőrzésére a lakosság védelmében van szükség, hogy ne tudják a mózesi vallási reform visszafordításával destabilizálni az országot, mert ennek a környező népekhez történő asszimiláció lenne a következménye. A passzus az állambiztonsági törvények előfutára.

\subsection{A megszentelendő Név}

„III. Az Úrnak a te Istenednek nevét biába fel ne vedd; mert nem bagyja ą̧ az Úr büntetés nélkül, aki az ő nevét biába felveszi."

\subsubsection{A közbeszéd tisztasága}

Szentségtörés és hamis eskü elleni törvény, mely a közbeszéd tisztaságát volt hivatott biztosítani, hiszen kimondja, hogy a szent Név nem tehető profánná. A káromkodás, átkozódás büntetésére volt precedens a pusztai vándorlás korszakában. ${ }^{26}$ Miután az ünnepélyes eskütétel egyfajta invokáció is volt, a törvény elrettentett a könnyelmű esküdözéstől, ezáltal az adott szó jelentőségére hívta föl a figyelmet. Az Újszövetségben Jézus az égre-földre esküdözést szükségképpen elbizakodott hazugságnak minősíti, ezért az egyenes beszédre szólít fel. ${ }^{27}$

A Tóra egyúttal a vallási állitások megvizsgálására nemcsak szabadságot adott, hanem egyenesen megkövetelte azt. Az Úr nevében bizonyíthatóan hazugságot állító egyének, az ún. hamis próféták rendszerint feleltek tettükért ${ }^{28}$, ami mai fogalmaink szerint a közgondolkodást irányítókkal szemben felállított magas mércére irányítja a figyelmet. Az objektív kritériumok felállitása továbbá a vallásokkal és vallási nézetekkel szembeni egészséges kritikai érzéket engedte kifejlődni. A vallások és vallási állítások bírálhatók, összemérhetők, ez a nézet szilárdan gyökeret vert a zsidókeresztény forrásokból táplálkozó gondolkodásban. Mindemellett a szabadság mellett a III. parancsolat magas erkölcsi színvonalat feltételez, olyan társadalmat, aminek a középpontjában Isten tisztelete áll, akinek személyazonosságát nem hamisítják meg, nevével nem élnek vissza. A szólásszabadság korlátait a blaszfémia tilalma jelenti.

\footnotetext{
255 Mózes 13:12-15

263 Mózes 24:14

${ }^{27}$ Máté 5:33-37

285 Mózes 18:20-22; Jeremiás 28.
} 


\subsubsection{A törvény uralma és a hatalmi ágak elválasztása}

Az eszményi Izrael papok birodalma, szent nép ${ }^{29}$, akiknek igazságos törvényeik vannak, jogrendje minta a többi nép számára. A jó jogrend kiemelkedően jogkövetővé tud tenni egy társadalmat. „Megtartsátok azért és megcselekedjétek! Mert ez. lesz a ti bölcsességtek és értelmetek a népek elött, akik meghallják majd mind e rendeléseket, és ezt mondják: Bizony bölcs és értelmes nép ę a nagy nemzet!"30 A teokratikus alkotmányon nyugvó társadalmi berendezkedés kivételes jelenség az ókori kelet viszonyai között, még akkor is, ha a teljes igazságosság elérendő ideál maradt. Minden emberre vonatkozóan a törvény uralma érvényesült és nem a kevesek, nem despoták vagy istenkirályok uralma. Három jelentős hivatal nyugodott a tórai jogon: aki a törvényt kihirdette: próféta volt, a törvény pedig szabályozta a papság és a civil hatóság (a királyság) intézményes kereteit, múködésük illetékességi körét.

Az Ószövetségben a királyi és papi funkció mereven elkülönült egymástól. Ez azt jelenti, hogy az állami és vallási hivatal nem fonódhatott össze. A szólásszabadságot képviselő próféta pedig mindkettőt bírálhatta. A zsarnokság kialakulását meggátoló ellenőrző funkciók annyiban levezethetôk belőle, amennyiben a királyi, prófétai, papi tisztségek egymást ellenőrző feladatkört láttak el, megteremtve ezzel a fékek és ellensúlyok rendszerét a társadalomban. A papok döntései vallási kérdésekben domináltak, de volt civil bíróság, a papok többnyire tanították, magyarázták a Törvényt. ${ }^{31}$ A legfelsőbb bíró a király volt. Ugyancsak a próféták emlékeztettek az Istentól kapott törvény szellemére, ha attól a nép elszakadt, vagy a hatalom elcsűrte-csavarta, és csak betújében tartotta meg. Az Újszövetségben Jézus, mint próféta hívta fel figyelmet a törvény életközpontú tartalmára, szemben annak puszta törvénykénti, formális megtartásával és emberi rendeletekkel való hatálytalanításával. ${ }^{32}$ A királyi és papi funkció elválasztása olyan modell, aminek messze ható következménye van a lelkiismereti- és vallásszabadság tekintetében. A papság és a királyság ószövetségi elkülönítése az állam és egyház szétválasztásának mintája lett a nyugati jogi gondolkodásban. Az egyház és állam szétválasztásának elve szerint a hatalom a hit dolgába nem avatkozhat bele, vallási ügyekben tartalmilag nem illetékes.

A jogi pozitivizmus felfogásával ellentétben a jognak abszolút (magától értetődő) erkölcsi törvényeken kell nyugodnia. A Tóra a társadalom minden szférájában megteremti az erkölcsi minimum alapját. Szükségképpen felmerül tehát a jogharmonizáció igénye is. „Óh, község! Nékteke és a köztetek lakozó jövevénynek egy rendtartástok legyen; örökkévvaló törvény legyen a ti nemzetségeiteknél, hogy az. Úr elött olyan legyen a jövevény, mint ti. Egy törvényetek legyen, és egy szabályotok néktek és a jövevénynek, amely közöttetek lakik." 33 A törvény uralma, a jogállam az a kívánatos társadalmi berendezkedés, amit a nyugati civilizáció magáénak vall. A törvény uralma jogbiztonságot jelent a hatóköre alá tartozó minden egyes polgár számára.

\footnotetext{
292 Mózes 19:6

305 Mózes 4:6

315 Mózes 17:9

32 Számos alkalommal, pl. Máté 15:1-9

334 Mózes 15:15-16
} 


\subsection{Munkaszünet és társadalmi igazságosság}

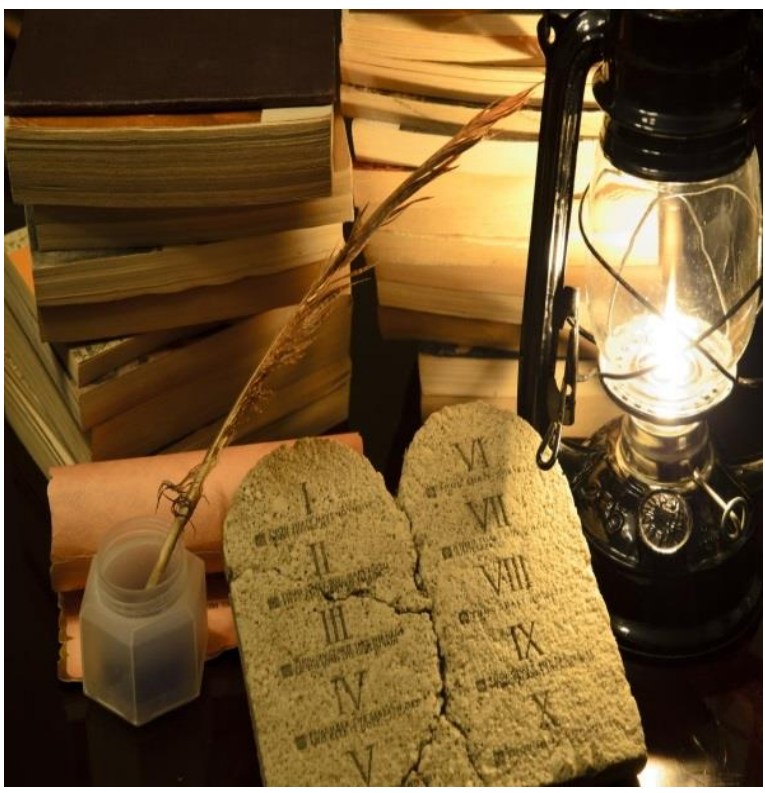

„IV. Megemlékezzél a szombatnapról, hogy megszenteljed azt. Hat napon át munkálkodjál, és végezd minden dolgodat; De a betedik nap az Úrnak a te Istenednek szombatja: semmi dolgot se tégy azon se magad, se fiad, se leányod, se szolgád, se szolgálóleányod, se barmod, se jövevényed, aki a te kapuidon belöl van; Mert hat napon teremté az. Úr az, eget és a földet, a tengert és mindent, ami azokban van, a hetedik napon pedig megnyugovék. Azért megáldá az Úr a szombat napját, és megszentelé åt.".

A szombattörvény az ember természetfölötti dimenzióját és értékét állítja elénk. Nem pusztán munkaerô, és sem az állam, sem a munka nem boldogítja. A személyes Isten az embert személynek tekinti, akivel személyközi kapcsolatban áll, és aki soha nem válhat eszközzé, nem tárgyiasodhat el. A gazdasági racionalitáson és társadalmi hasznosságon felül értékes. „Mert az én szolgáim Izráel fiai, az én szolgáim ök, akiket kihoztam Egyiptom földéröl. Én vagyok az. Úr, a ti Istenetek."”34

\subsubsection{A pihenőnap társadalmi hatása}

A pihenőnap elrendeléséből a társadalmi igazságosság eszménye vezethető le. Az Exodus társadalmi vívmánya az volt, hogy a rabszolgasorból egy nép kiemelkedett, és szabad lett; megkapta az önrendelkezés jogát. Heti egy napon pedig a megnyert szabadságával teljes mértékben élhet. A pihenőnap indoklása más megfogalmazásban ${ }^{35}$ az, hogy engedjék uraik a szolgáikat is pihenni, és emlékezzenek vissza, hogy rabszolgák voltak Egyiptomban. Mindenkinek jár egy pihenőnap, hogy regenerálódjon, függetlenül a társadalomban elfoglalt pozíciójától, nemétől, korától, vagy származásától. A parancs megfogalmazása a törvény előtti egyenlőséget erősíti meg. A pihenőnap össztársadalmi hatását tekintve rendkívül pozitív intézkedés, hiszen mindenki számára törvény által biztosítja a szabadidőt, hogy visszanyerje fizikai, mentális és lelki egészségét. A pihenés mai fogalmaink szerint a kiégés elkerülését és a kreatív energiák megújulását eredményezi.

A Törvényben a szombattörvények egész skálájáról olvasunk. A szombattörvény vallási jelentőségén túlmenően szociális intézkedéscsomagot foglalt magában. ${ }^{36}$ Hétéves ciklusokban elrendelték a rabszolgák felszabadítását Hétszer hét év számlálása után következő minden

\footnotetext{
343 Mózes 25:55

355 Mózes 5:15

363 Mózes 25:1-55
} 
ötvenedik esztendőben felszabadultak az adósok, az eladósodottak visszakaphatták elzálogosított birtokukat. A szombatév a vagyoni különbségeken jelentősen enyhített, az ötvenedik esztendő, a jubileumi év pedig lehetôvé tette a tartósan eladósodottak számára az újrakezdés esélyét, a lecsúszott társadalmi rétegeknek a konszolidált életmódba való visszakapaszkodást.

A Tóra a termőföld parlagon hagyását is elrendelte, hogy pihentetésével megújuljon a föld termőereje. A vetésforgó európai bevezetése szintén a föld pihentetésén alapul, ami által nagyobb termést értek el. A nagyobb termésátlag több élelmiszert, jobban táplált lakosságot és jobb életminőséget, akár nagyobb születésszámot jelent.

Az önrendelkezéshez szükséges az egészség, amivel az egyén képes az öngondoskodásra. Az egészség és a munkaképesség értékére tekintettel, egy közösség tagjai egymás egészségéért kölcsönösen felelősek. „És ha férfiak összevesznek, és megüti valaki az ö felebarátját kốvel vagy öklével, és nem hal meg, hanem ágyba esik: Ha felkél, és mankóján kinn jár: ne legyen büntetve aそ, aki megütötte; csupán fekvéséert fizessen és gyógyittassa meg." ${ }_{37} \mathrm{Ha}$ valaki embertársa testi épségét, munkaképességét megkárosította, a törvény kötelezte, hogy fizesse ki annak egészségügyi ellátását, és a munkából kieső napokat táppénz gyanánt. A fenti törvényben a betegbiztosítás gyökereit láthatjuk.

\subsection{A család védelme}

„V. Tiszteld atyádat és anyádat, hogy hosszú ideig élj azon a földön, amelyet az Úr a te Istened ád te néked."

A törvényeket pozitív és negatív előjellel ellátva beszélhetünk pozitív parancsokról, (tedd ezt és ezt) és negatív parancsról, azaz tiltásról. A törvények megfogalmazása néhol tartalmaz indoklást, néhol egyetlen kategorikus tilalomból áll. Az ötödik parancsolat egy felszólítás, amihez ígéret is fűződik, méghozzá a hosszú és jó élet ígérete, olyan földön, melyet Isten jelölt ki az embernek. A család funkciójának felértékelése, a szülők tisztelete és a szülőföld szeretete természetes módon összekapcsolódik.

Az első földi intézmény eredetét és jelentőségét tekintve is a házasság és a család. Az egyén számára szintén az első emberi közösség, amelynek részévé válik. Mivel a házasság kölcsönös szereteten alapul, a családban alakul ki a gyermek önértékelése és életigenlő mentalitása. A szülők kötelessége szeretettel gondozni a gyermeket, a szülőket pedig megilleti a tisztelet az életadásért és gondoskodásért. A társadalom szövete az egészséges családok sejtjeiből fejlődik ki és épül tovább. A tisztelet parancsa teszi lehetôvé az egyén számára minden más, alá-fölérendeltségen alapuló viszonyba való beilleszkedést. Más szóval bármely tekintélyi rendbe való betagozódás, együttmúködési készség kialakulása a szülők tiszteletével kezdődik.

A tisztelet kultúrájának meghonosítása a nevelés által történik és elengedhetetlen ahhoz, hogy nagyobb emberi közösség jöhessen létre. Aki a kisebb, az a családi közösségben együttműködést tanul és képes a nagyobb közösségben is értékteremtő és értékhordozó ember lenni. A család nemcsak szociális készségeket segít elsajátítani, hanem ismereteket is. A szülő az első nevelő, akinek ebbéli kompetenciáját ez a parancsolat megerősíti, miután a következő nemzedékekért vállán nyugvó felelősségére az első két parancsolat már felhívta a figyelmet. Az

\footnotetext{
372 Mózes 21:18-19
} 
oktatás, nevelés kiemelkedő fontosságára világít rá, ami nélkül semmilyen interperszonális kapcsolatra vonatkozó parancsnak nem lenne foganatja. A következő nemzedék nevelése, tanítása elsősorban szülői feladat, de az ismeretek széles skáláját lehetőleg minden gyermeknek egységesen átadni a közoktatás által lehetséges. ${ }^{38}$ A szülők mint életadók és nevelők tekintélyükben azért nyernek védelmet és megerősítést, mert a Törvényadó életpárti, jövőorientált társadalmat vizionál, ahol az egyén tehetsége fejleszthető.

Az V. parancsolatban a szociális háló szükségessége, a társadalmi gondoskodás alapgondolata is benne van. A szülő tisztelete az idős szülő eltartását, ellátását is magában foglalja, ezáltal a nyugdíjrendszer ősének tekinthető. A családon túlnövő gondoskodás a szegények megsegítése, a jótékonykodás. A kiszolgáltatott emberek közösségi segitése, életlehetőséghez és ellátáshoz juttatása kifejezett parancs. Az árvák, jövevények, özvegyek felkarolása olyan tevékenység, melyeket a Tóra kifejezett parancsba adott. ${ }^{39}$ Kifosztásuk, ellehetetlenítésük égbekiáltó bűn, amitôl nemcsak a Törvény, hanem a próféták és a tanító jellegû írások óva intenek.40 Kiszolgáltatott lehet a munkaadójának az alkalmazott is, akinek visszatartják a bérét.

Az utolsó júdabeli írópróféta, Malakiás tolmácsolásában a Seregek Ura perel azért, hogy a társadalom állapota javuljon. „Mert itéletre indulok hozzátok, és gyors tanú leszek a szemfényvesztók ellen, a paráznák és hamisan esküvök ellen, és azok ellen, akik megröviditite a munkásnak bérét, az özvegyet és árvát, és akik nyomorgatják az idegent, és nem félnek engem, ąt mondja a Seregeknek Ura." ${ }^{41}$ Az idősek tisztelete szintén tórai parancsolat, amely fontos érték a tekintélytiszteleten alapuló társadalmakban. Legköznapibb alkalmazása törvény szövegének a felirat, amely a modern Izraelben a tömegközlekedési eszközökön szólítja fel az utasokat, hogy adják át helyüket az időseknek. Így szól: „Az ő̌sz ember elött kelj fel". ${ }^{42}$

\subsection{Az emberi élet védelme}

$$
\text { „VI. Ne ölj.” }
$$

A Teremtés könyvéből egyértelmú, hogy az emberi élet a jog által védendő legfontosabb érték. Az ölést kifejező héber szó gyöke (rácah) kifejezetten az emberölésre, a gyilkosságra vonatkozik. Az emberi élet egyszeri, megismételhetetlen, mivel visszaadni emberileg lehetetlen, ezért életet elvenni sem szabad. Emberi életet kioltani bűn. Az emberölés szankcionálása jóval régebbi, mint a mózesi törvény.

Az Édenből való kiűzetést követően azonnal megtörtént az emberi élet kioltása miatti felelősségre-vonás Káinnal szemben, amiért megölte testvérét, Ábelt.43 „Monda pedig az Úr: Mit

\footnotetext{
${ }^{38}$ Az első ismert, egységes, közpénzből fenntartott iskolarendszert a Hasmoneus uralkodóház vezette Júdeában állíttatta fel Simon ben Setach, farizeus tudós, a Szanhedrin feje, i.e. 75-ben.

395 Mózes 14:29; 16:11-14

402 Mózes 22: 22; Jeremiás 22:3; Ezékiel 22:7; Zakariás 7:10; Példabeszédek 23:10-11

${ }^{41}$ Malakiás 3:5

423 Mózes 19:32a

431 Mózes 4:8-15
} 
cselekedtél? A te atyádfiának vére kiált én hozzám a földröl." ${ }_{44}$ Emberi bíróság még nem ítélte el és nem büntethette meg a gyilkost, kizárólag Isten szava sújtott le a lelkiismeretére.

\subsubsection{Az államhatalom legitimációja}

Az emberi élet védelmében a vízözön után, Noéval kötött szövetség keretében Isten feljogosította az embereket a gyilkosság megtorlására, ezáltal a bíróság és a büntetőhatalom felállítására adott parancsot: „Aki ember-vért ont, annak vére ember által ontassék ki; mert Isten a maga képére teremté az. embert."45 A mondat ritmikus és szimmetrikus verssor, amely tartalmazza magára az igazságszolgáltatásra vonatkozó törvényt, az emberölés esetében kiszabandó büntetési tételt az elkövetőre, és annak bírói indoklását. Az igazságszolgáltatás alapelve a lex talionis, a tett súlyával arányos büntetés elve. Ez az utasítás az emberi közösségekben egyetemlegesen a bíróság felállítására, és a büntetőhatalom létrehozására adott felhatalmazást, ami az államok kialakulásához vezetett. „Isten a gyilkosságot már Noé idejében büntetni rendelte (1 Mózes 9:6), a ’Ne ölj? parancsa később erre erősített rá." 40

A dekalógust követő és magyarázó polgári törvények továbbá részletezik a testi sértés, a súlyos testi sértés esetében kiszabandó büntetéseket és a véletlen baleset okozásakor bekövetkező haláleseteket, amikor a közkegyelem intézménye léphet múködésbe. Ennek a formája a mózesi törvényben a menedékvárosok rendelése, ahol a vérbosszú elől védelmet kapott a nem szándékos emberölést elkövető ember. A gyilkosok halálbüntetéssel sújtása adja az állam és büntetőhatalmának legitimációját. Figyelemreméltó, hogy a Törvény meghagyta a szokásjogot, melynek alapján saját hatáskörben is eljárhattak az ókori Izraelben: rokon is bosszút állhatott megölt rokonáért a gyilkoson ott, ahová az állam keze nem ért el. Ebből is látszik, hogy a gyilkosok halálbüntetése nemcsak elrettentésül szolgált, hanem igazságot is szolgáltatott az áldozat családjának. Ugyanakkor az áldozat családtagja fellebbezhetett ez ellen. Egy realisztikus jogesetről olvasunk Dávid király krónikájában, melyben egy anya a királytól kér védelmet a rokonsággal szemben, hogy ne veszítse el megmaradt fiát, aki másik fiát megölte. ${ }^{47} \mathrm{Az}$ önbíráskodás helyett a modern polgári társadalomban a polgár az államra ruházta a fegyver viselésének jogát. A fegyverviselés ma is kérdéseket vet fel: van ahol szinte teljesen, van ahol kevésbé állami monopólium. A polgárok és az állam szerződésén múlik, mit tekintenek az élet leghatékonyabb védelmének.

\subsubsection{Az élet védelme fogantatástól a természetes halálig}

Hasonlóan nagy vita tárgya az önrendelkezés joga és mások élethez való jogának ütköztetése. Az emberi élet bibliai szemléletét védelmezők szerint az élet a fogantatástól a természetes halálig tart. Ennek a koncepciónak megfelelően az abortusz, az eutanázia (és az öngyilkosság) egyaránt emberi élet szándékos, önkényes kioltása, per definitionem emberölés. A magzat, noha önálló életre még

\footnotetext{
441 Mózes 4:10

451 Mózes 9:6

${ }^{46}$ MÉSZÁros, Bibliai államelmélet 19.

472 Sámuel 14:1-11
} 
képtelen, nem tekinthető az anya testrészének, mert teste kezdettől egyedi és sajátos; már az anyaméhben személyiségjegyekkel rendelkezik ${ }^{48}$, ennél fogva jogalany, élete méltó a védelemre. „Bizony te alkottad veséimet, te takargattál engem anyám mébében. (...) Látták szemeid az én alaktalan testemet, és könyvedben ezek mind be voltak irva: a napok is, amelyeken formáltatni fognak; bolott egy sem volt még meg köəülï̈k.”" Az emberi testet nagyra becsüli a Szentírás. „Nemcsak az emberélet szent, hanem az Isten képére formált emberi lény is nagy becsben áll." ${ }^{50}$

\subsection{A házasság védelme}

\section{„VII. Ne paráználkodjál.”}

A VII. parancsolat a szexuáletika témakörét öleli fel. A héber kifejezés (näaf) a házassági hủtlenség tényállására utal, a házasság nélküli viszonyok közül külön szó csak a prostitúcióra van, ezért átfogó értelemben mindennemú nemi erkölcsbe ütköző cselekményt érthetünk alatta. Az európai jogfelfogás a keresztény, evangéliumi törvényértelmezést a tekintette hosszú ideig iránymutatónak, ami a monogám házasságot, az egy férfi és egy nő szövetségén alapuló házasság intézményét törvényi védelemben részesíti. A magyar Alaptörvény mindeddig a hagyományos házasságot ruházza fel különleges státusszal. Az élethosszig tartó, kölcsönös hűségen és szereteten alapuló házasság biztosítja férfi és nő számára az utódnemzéshez szükséges érzelmi, fizikai és anyagi biztonságot, ami egyben a gyermekek legjobb környezetét jelenti és a felnevelésükkel járó terhet megkönnyíti. A szülői tisztelet kapcsán már szó esett a család szükségességéről és társadalmi hasznáról. A hűségen alapuló monogám házasság a lelki és testi egészség számára is kedvező. Minimálisra szorítja a szexuális úton terjedő betegségek kockázatát, melyeknek önmagában is képes (lenne) gátat vetni. ${ }^{51}$ A népesség növekedését leginkább a monogám házasság tudja biztosítani egy nemzetben. A házasság polgári szerződés, amiből jogok és kötelezettségek származnak. A válást a tórai jog enyhébben, az Újszövetség szigorúan ítéli meg, de közös abban, hogy formális keretei vannak, törvényes indoklás nélkül nem szűnik meg. ${ }^{52}$

A Tóra tiltja a házasságon kívüli, a közeli rokonok közötti és az egynemúek közötti nemi kapcsolatot, továbbá az állatokkal való nemi közösülést. ${ }^{53}$ A gyermekáldozat tiltása ugyanabban a törvénycsomagban kapott helyet, mint a vérfertőzés és perverzió tilalma. A „Ne paráználkodj” parancsolat hatálya alá tartoznak a különféle, a nemi erkölcsbe ütköző cselekmények, például a nemi erőszak eseteinek szankcionálása ${ }^{54}$, amit a modern polgári állami törvény továbbra is szankcionál. A prostitúciót úgy tiltja, hogy a fiatalra döntő befolyással bíró személyt, jelesül a patriarkális családban az apákat szólítja fel, hogy ne becstelenítsék meg a lányukat azzal, hogy prostituáltnak adják. Ilyen módon a törvény a prostituáltat magát inkább áldozatnak tekinti, a prostitúció

\footnotetext{
${ }^{48}$ Zsoltárok 139:13-16; Jeremiás 1:5; Lukács evangéliuma 1:43-44

49 Zsoltárok 139:13,16

${ }^{50}$ JOHNSON, A zsidók története 50.

51 MCMillEN, Elkerülhető betegségek 42-51.

52 Máté 19:1-9, ahol Jézus utal a könnyítést jelentő válólevélre.

533 Mózes 18

545 Mózes 22:23-27
} 
irányában befolyásoló környezetet pedig felelősnek. Az okot és nem pusztán a negatív társadalmi jelenséget, mint okozatot kívánja megszüntetni. ${ }^{55}$

\subsection{A magántulajdon védelme}

„VIII. Ne lopj.”

A VIII. parancsolat a magántulajdonhoz való jog védelmét biztosító törvény. A magántulajdonban egy személy életideje, tehetsége, munkája testesül meg, ezért védelem alatt áll. Más tulajdonának elvétele törvénybe ütközik, amit a Tóra szankcionál. Mózes törvénye egyedülálló újdonsága volt az i.e. 2. évezred ókori keleti jogi környezetében, hogy az ember értékét messze az anyagi értékek fölé emeli. Míg Hammurapi törvényei a lopás miatt (egy kivétellel) minden esetben halálbüntetést róttak ki56, Mózes törvénye egyetlen esetben, az éjszakai betörővel szembeni jogos önvédelem esetében ismeri el annak jogosságát, fényes nappal a tolvaj életének a kioltása ugyanúgy gyilkosságnak minôsül, mint más emberölés. Míg a mezopotámiai kódex csak a közönséges lopás egy enyhe esetében engedte a tolvajnak, hogy kárpótlás megfizetésével mentesüljön a büntetés alól, de ha fizetésképtelen volt, akkor ő is életével fizetett; addig Mózes törvénye rendszerint a kár megtérítését írta elő, a rablás, lopás, sikkasztás, hűtlen kezelés eseteiben, az elkövetőt különböző mértékủ pénzbeli kárpótlás megfizetésére kötelezve.

Az emberrablás esetében viszont éppen fordítva van: a tórai rendelkezés szerint „aki embert lop, és eladja, halállal lakoljon." ${ }_{57}$ Ez a szabály viszont ismét azt az értékrendet erősíti meg, hogy az ember nem lehet árucikk. A túszejtőkkel szembeni rendőri, katonai fellépés etikai vetületét megvilágíthatja, hogy aki embert lop, nem egyszerú tolvaj, hanem egy emberi életet tesz tönkre, megfosztva eredeti rendeltetésétől. A tórai szabályozás tehát az ember anyagi javakkal összemérhetetlen értékére mutat rá. Az emberrablás kategóriájába nemcsak a túszejtést sorolhatjuk, hanem a rabszolga-kereskedelmet, az emberi test áruba bocsátása céljából zajló emberkereskedelmet, valószínúleg számos esetben a kerítéssel, futtatással, prostitúcióval anyagi haszonra szert tévő szervezett bűnözők tevékenységét is. Az emberkereskedelmet tiltó törvény mindezeknek a káros társadalmi jelenségeknek hathatósan elejét vette. Bővebb megfogalmazása így szól: „Hogyha rajtakapnak valakit, aki embert lop az ő atyjafiai közül, Izráel fiai közül, és hatalmaskodik. rajta, vagy eladja ąt: haljon meg az a tolvaj. Így tisztitsd ki a gonosz̨t te közülled." 58 Különféle károkozások is a „ne lopj” kategóriájába sorolhatók. A magántulajdon védelmére vonatkozó további törvények tiltják az olyan anyagi természetû visszaéléseket, mint a hűtlen kezelés, sikkasztás, orgazdaság, zsarolás (magántulajdon erőszakkal, fenyegetéssel való megszerzése) és a csalás, amire a kettős mérce tilalma vonatkozik. „Ne kövessetek el igazságtalanságot az itéletben, a hosszmértékben, súlymértékben és ûrmértékben." ${ }^{99}$ Még plasztikusabban fejezi ki ugyanezt egy másik törvény, ami a pénz és a szemes

\footnotetext{
553 Mózes 19:29

56 Hammurabi törvényei 6-11. \$S, 15.

572 Mózes 21:16

585 Mózes 24:7

593 Mózes 19:35
} 


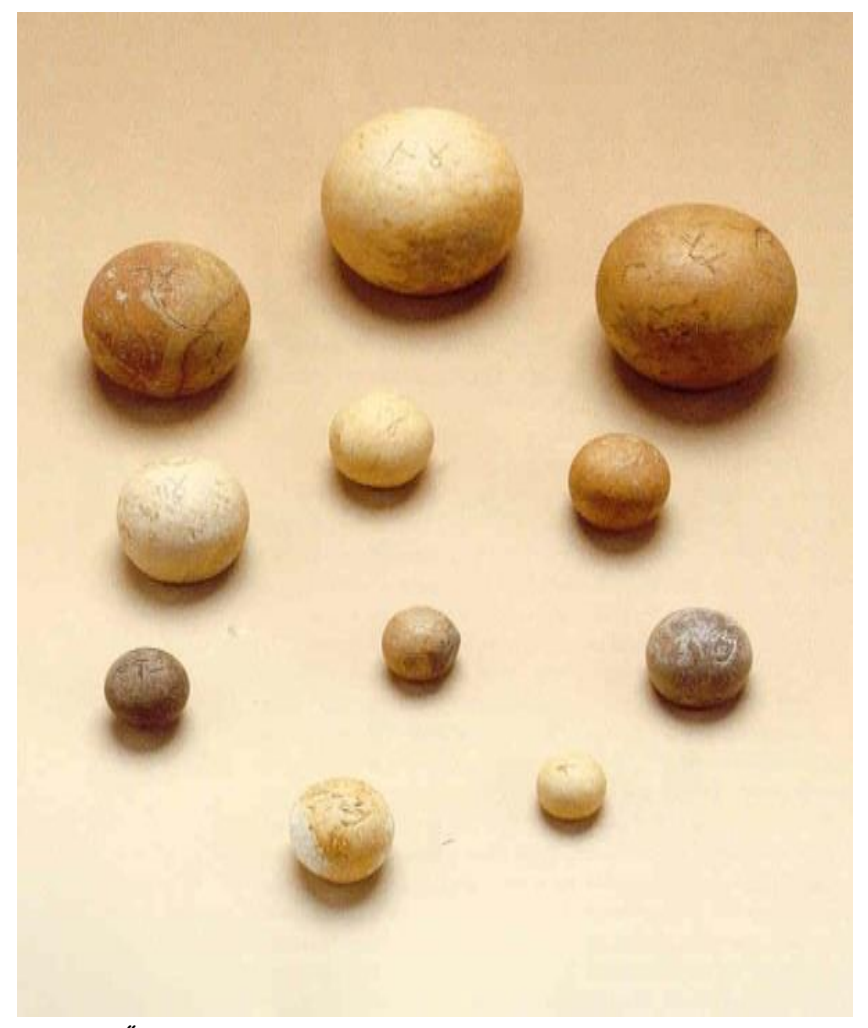

5. kép: Ősi súlymértékek Izraelben termény mérésére alkalmas eszközöket egységesíti: „Ne legyen a te zsákodban kétféle font: nagyobb és kisebb. Ne legyen a te házadban kétféle éfa: nagyobb és kisebb."60 A kétféle mérték és súly tilalma a fogyasztóvédelem korai előfutára volt, hiszen a mérésben történő csalással a vevôt be lehetett csapni, és az eladó a kisebbé tett mércével rejtett árdrágítást ért el, ezzel vevőjét megrövidítette. A próféták az igazságosságot kérték számon kortársaikon, így Ámós ${ }^{61}$ társadalombírálata a csalást sem hagyta szó nélkül: „Mikor múlik el az újhold, hogy gabonát árulhassunk? És a sqombat, hogy megnyithassuk a gabonás házat? Hogy megkisebbitsük a vékát, és megnagyobbitsuk azárát, és hamis mértékeel csalhassunk? Hogy meguegyük a szegényeket pénzen, és a sqükölködöt egy öltö saruért, és eladhassuk a gabona bulladékát?'"62

A Szentírás elítéli nemcsak a gazdasági elit, hanem a politikai hatalommal visszaélését az állampolgárral szemben. Az állampolgár magántulajdonának kisajátítását súlyos következményekkel járó törvénysértésnek tekinti. Szabadság nincsen vagyonbiztonság nélkül. Az állami erőszakkal, az igazságszolgáltatás gépezetével végbevitt rablást egy híres eset, Nábót szőlője kisajátítása példázza (1 Királyok 21.). Az esetben az uralkodó a maga számára kiszemelt ingatlant úgy szerezte meg, hogy tulajdonosát hamis vád alapján kivégeztette és a tulajdont elkobozta. Az anyagi haszonszerzés indítékából elkövetett gyilkosságra és az indíték jelentőségére a X. parancsolatnál térek vissza. Itt csak magát a koncepciós per általi kisajátítást említem a „ne lopj” parancs kapcsán, ami mindenkire egyaránt vonatkozik. A törvényes közhatalomról alkotott európai felfogás szerint a magántulajdontól a polgárt az államhatalom sem foszthatja meg.

\subsection{A jó hírnév védelme}

\section{„IX. Ne tégy a te felebarátod ellen hamis tanúbizonyságot."}

A IX. parancsolat a hamis tanúzás tilalma. A hamis tanú hazugságot mond ${ }^{63}$, ezért a törvény etikai értelme általánosságban a hazugság tilalma. A hamis tanúzás tilalma speciális

\footnotetext{
605 Mózes 25:13-14

${ }^{61}$ Ámós próféta i.e. 745-ig tevékenykedett Izraelben, II. Jeroboám uralma alatti viszonylagos jólét időszakában.

62 Ámós 8:5-6

${ }^{63}$ Példabeszédek 6:19
} 
értelemben a bíróság előtt tett hamis tanúzást mondja ki, tekintettel annak különös súlyára. Hamis tanúzással egy ártatlan ember becsületét, tulajdonát, sőt életét lehet elvenni abban az esetben, ha a bíróság hamis tanúvallomás alapján hozza meg döntését. ${ }^{64} \mathrm{~A}$ parancsolat feltételezi a bírósági hivatal fennállását és döntéshozatali mechanizmusát a vádtól a végrehajtásig.

\subsubsection{A bíróság előtt}

A Tóra egyik jelentős értéke az igazságos és méltányos eljárás iránti követelmény. A bíróság felállításának elrendelésekor megfogalmazza a bírákkal szemben igazságos, pártatlan, megfélemlítéstől és elfogultságtól mentes itélethozatal követelményét. „Bírákat és felügyelöket állits minden kapudba, amelyeket az Úr, a te Istened ád néked, a te törzseid szerint, hogy itéljék a népet igaz. itélettel. El ne forditsd az itéletet; személyt se válogass; ajándékot se végy; mert az ajándék megvakitja a bölcsek szemeit, és elfordítja az igazak beszédét. Igazságot, igazságot kövess, hogy élhess, és örökségül birhasd azt a földet, amelyet az. Úr, a te Istened ád néked." ${ }^{5} \mathrm{Az}$ utolsó passzus kétszeresen megismétli az igazság szót, amit többféleképpen értelmez rabbinikus jogtudomány. Egy lehetséges magyarázata, hogy igazságot úgy kell szolgáltatni, hogy közben maga az eljárás is igazságos. ${ }^{66}$ Rossz eszközzel nem lehet jó cél érdekében tenni az igazságért. A törvény ilyen interpretációjából az következik, hogy helyes ítélet is lehet formai hiba miatt kifogásolható, vagy fordítva, formálisan kifogástalan eljárásban is születhet hibás döntés. A kövess szó a héber szövegben úgy is fordítható, hogy menj utána, vagy akár úgy is, hogy üldözd. Ez azt jelenti, hogy az eljárás indul, az ügyet végig kell vinni, egészen addig, amíg a bírák vagy felügyelők el nem érik az igazságosságot. A felügyelőket mai fogalmainkkal a rendőrséggel helyettesíthetjük be.

A bíróságnak pártatlannak, függetlennek és megvesztegethetetlennek kell lennie. A bírónak személyválogatás nélkül, kizárólag a törvények alapján kell ítéletét meghozni. A törvény előtti egyenlőség azt jelenti, hogy vagyoni helyzetre való tekintet nélkül kell a bírónak a felek számára igazságot szolgáltatnia. Mózes a fenti meghagyásokon túlmenően a bírákat felszólította arra, hogy hallgassák ki az embereket, továbbá, hogy senkitôl ne féljenek, mert az ítélet Istené. ${ }^{67}$ A bírák tehát nem a saját maguk, hanem a Törvény nevében járnak el, ezért jó okuk van arra, hogy megfélemlítés nélkül végezzék munkájukat.

\subsubsection{Hamis tanúzás büntetése}

A tisztességes eljáráshoz fűződő jog elve tükröződik abban, hogy mindkét felet (képviselőiket, tanúikat is) meg kell hallgatni. A tanúkat különösen nagy felelősség terhelte egy olyan korban, amikor a szem-és fültanúk vallomása döntő súllyal esett latba egy-egy döntésben (hiszen a

\footnotetext{
${ }^{64} \mathrm{Pl}$. Nábót szőlője esetében, vö. 1 Királyok 21

655 Mózes 16:18-20

${ }^{66}$ Rav Ási szerint az igazság (cedeq) szó ismétlése azért van, mert kétféle igazságosságot jelent: a törvény szigorú alkalmazását és a józan észen nyugvó kompromisszumot (Jeruzsálemi Talmud, Szanhedrin 32b). A lengyel haszid Rabbi Szimcha Bunim (1765-1827) szóbeli tanítása szerint viszont az idézett vers értelme az, hogy az eljárásnak, melynek során igazságot tesznek, magának is igazságosnak kell lennie. Miærabi ezt így idézi: „Justice for legitimate ends, and justice by legitimate means."

675 Mózes 1:16-17
} 
nyomozáshoz és a bizonyításhoz nem álltak rendelkezésre fejlett technikai eszközök). A hamis tanúzás tilalma magában foglalja a jó hírnévhez füződő jog védelmét. A hamis tanúbizonyság tilalma a hamis vád emelésének tilalmát is jelenti, más szóval a rágalmazást. A tanúskodásról szóló törvény három fontos elemet tartalmaz: egyrészt az ártatlanság vélelme megilleti a vádlottat, másrészt a bizonyítás terhe a vád oldalán van, harmadrészt minimálisan két vagy három tanú egybehangzó vallomása alapján jön létre bírósági ügy.

A hamis tanúra a lex talionis szabálya szerint szabták ki a büntetés mértékét. Figyelemreméltó tény, hogy a mózesi törvény „sžemet szemére’ elve a perrel elérni szándékozott sérelemre is kiterjedt, nem csak a ténylegesen elkövetett testi sértésre. „Ne álljon elo egy tanú senki ellen semmiféle hamisság és semmiféle bün miatt; akármilyen bünben bünös valaki, két tanú squavára vagy három tanú szavára álljon a dolog. Ha valaki ellen gonosz tanú áll eló, hogy pártütéssel vádolja ốt: Akekor álljon az a két ember, akiknek ilyen perük van, az Úr elé, a papok és a birák elé, akik abban az idóben lesznek; És a birák viasgálják megjól a dolgot, és ha hazug tanú lesz a tanú, aki hazugságot szólott a zó atyjafia ellen: Úgy cselekedjetek azzal, amint ö sqándékozott cselekedni az ö atyjafiával. Így tisztitsd ki közüled a gonoszt; Hogy akik megmaradnak, ballják meg, és féljenek, és többször ne cselekedjenek te köpötted ilyen gonosz dolgot. Ne nézz reá szánalommal; lelket lélekért, szemet szemért, fogat fogért, kez̨et kézért, lábat lábért."08

Mindaddig, amíg a vád nem nyer bizonyítást, a gyanúsítottat megilleti az ártatlanág vélelme, nem kezelhetô az elítélttel egy szinten. A bizonyítás terhe pedig a vád oldalán van, ami szintén az ember jó hírnevéhez való jogát engedi érvényesülni.

\subsubsection{Egy tanú nem tanú}

Halálbüntetést kizárólag két, vagy három tanú vallomására volt szabad kiszabni. A tanúknak vállalni kellett az ítélet jogosságáért a felelősséget. „Két tanú vagy bárom tanú szavára halállal lakoljon a halálra való; de egy tanú szavára meg ne haljon. A tanúk kęe legyen elsö rajta, hogy megölettessék, és azután mind az. egész. nép kę̧e. Így tisztitsd ki magad közül a gonoszt.”" Az európai jogi kultúrában a unus testis nullus testis formában összegzett alapelv már a tórai jogban megjelent. Az első követ a tanúknak kellett a vádlottra dobniuk. Erre a joggyakorlatra utal Jézus, amikor egy tetten ért házasságtörő nőt azzal mentett ki vádlói kezéből, hogy felszólította a vádat képviselőket, hogy az vesse rá az első követ, aki nem vétkezett. ${ }^{70}$

\subsubsection{Hallgattassék meg a másik fél is}

A másik fél meghallgatása az igazságos és tisztességes eljárásnak szintén alapvető kritériuma. A latin szállóige formájában rögzült elv (audiatur et altera pars ${ }^{71}$ ) beépült az európai jogi gondolkodásba. „Isten és ember törvényei egyaránt megadták a lehetőséget a másik félnek, hogy védekezzen, ha van valami mentsége (...) még maga Isten sem mondott ítéletet Ádámra azelőtt, hogy felszólította ôt,

\footnotetext{
685 Mózes 19:15-21

695 Mózes 17:6

70 János evangéliuma 8:7

${ }^{71}$ SENECA, Medea 199. Audi alteram pars („halld a másik felet”) formában Augustinus (The two souls 14:22) is használja.
} 
hogy szóljon a védelmére." 72 Az emberpár élhetett a védekezés lehetőségével és beismerő vallomást tehetett. Az ítélethirdetés előtt minden ügyben kérdezni kell, ez indokolja az ügyek nyomozati szakaszát. Az Újszövetség lapjain visszaköszön a tisztességes eljárás elve a korabeli ítélkezés gyakorlatában. „Vajon a mi törvényünk kárhoztatja-é az embert, ba elöbb ki nem hallgatja, és nem tudja, hogy mit cselekssik??'73

Salamon, a bölcs király egy velős mondásban foglalja össze, miért fontos mindkét felet meghallgatni. Mikor szót kap a másik fél, rávilágít az első érvelésének gyenge pontjaira: „Igaza van annak, aki elö a perben; mignem eljö az. ő peresfele és megvizsgálja ơt." 74

\subsection{A magánélet sérthetetlensége}

„X. Ne kivánd a te felebarátodnak házát. Ne kivánd a te felebarátodnak feleségét, se szolgáját, se szolgálóleányát, se ökrét, se sqamarát, és semmit, ami a te felebarátodé." 75

A dekalógus X. cikkelye a privátszféra védelmének etikai elvét fogalmazza meg. Minden ember életideje és tehetsége munkája eredményében és szúkebb és tágabb kapcsolatrendszerében, egzisztenciájában jelenik meg, amelyek földi boldogulásának feltételei. A kívánság, vagyis a másik ember eredményeinek, javainak, állapotának megirigylése mélyen gyökerezik az emberi természetben. Ha cselekedet szintjén nem is megfogható, az irigységre való hajlam felfedése a törvény feladata volt. Pál apostol így vall erről: „a bünt nem ismertem, hanem csak a törvény által; mert a kivánságról sem tudtam volna, ha a törvény nem mondaná: Ne kivánjad." 76 Az irigységet az állami törvény nem szankcionálja, de az isteni törvény fontosnak tartotta, hogy tükröt tartson az ember elé, hogy gátat vessen az irigység által motivált gonosztetteknek. A Szentírás több bűntény hátterében az irigységet, vagy féltékenységet sejteti: az első gyilkosság indítéka az irigység volt. Káin megölte testvérét, Ábelt, mert Ábel áldozata elnyerte Isten tetszését, az övé pedig nem. ${ }^{77}$ Józsefet irigységből kis híján megölték, végül csak eladták rabszolgának a testvérei. ${ }^{78} \mathrm{Az}$ irigység volt Nábót szőlője fondorlatos megszerzése és kivégzése mögött, és a sort még hosszan lehetne sorolni.

A salamoni ítélethozatal közmondásosan bölcs, amelynek kapcsán meg kell említenünk magát a konkrét jogesetet. ${ }^{79}$ Egy házban lakott két nő, mindkettő gyermeket szült. Az egyik megvádolta a másikat, hogy az ráfeküdt a gyermekére, és éjjel, míg ő aludt, ellopta mellőle a gyermekét, és kicserélte a maga halott gyerekére. A másik nő a vádat tagadta, és az élő csecsemőt sajátjának mondta. Az életben maradt újszülött fölött vitatkozó felek között Salamon, Júda királya - színleg - úgy döntött, hogy vágják kétfelé a gyermeket, hogy az asszonyok között egyenlőképpen osszák el. Az egyik nő igazságosnak tartotta a döntést, a másik könyörögni kezdett: inkább odaadja, csak kíméljék meg a gyermek életét.

\footnotetext{
${ }^{72}$ Lásd EYRE bíró megjegyzését (1722) http://www.duhaime.org/LegalDictionary/A/Audialterampartem.aspx

73 János 7:51

74 Példabeszédek 18:17

752 Mózes 20:1-17

76 Róma $7: 7 b$

771 Mózes 4:3-8

781 Mózes 37

791 Királyok 3:16-28
} 


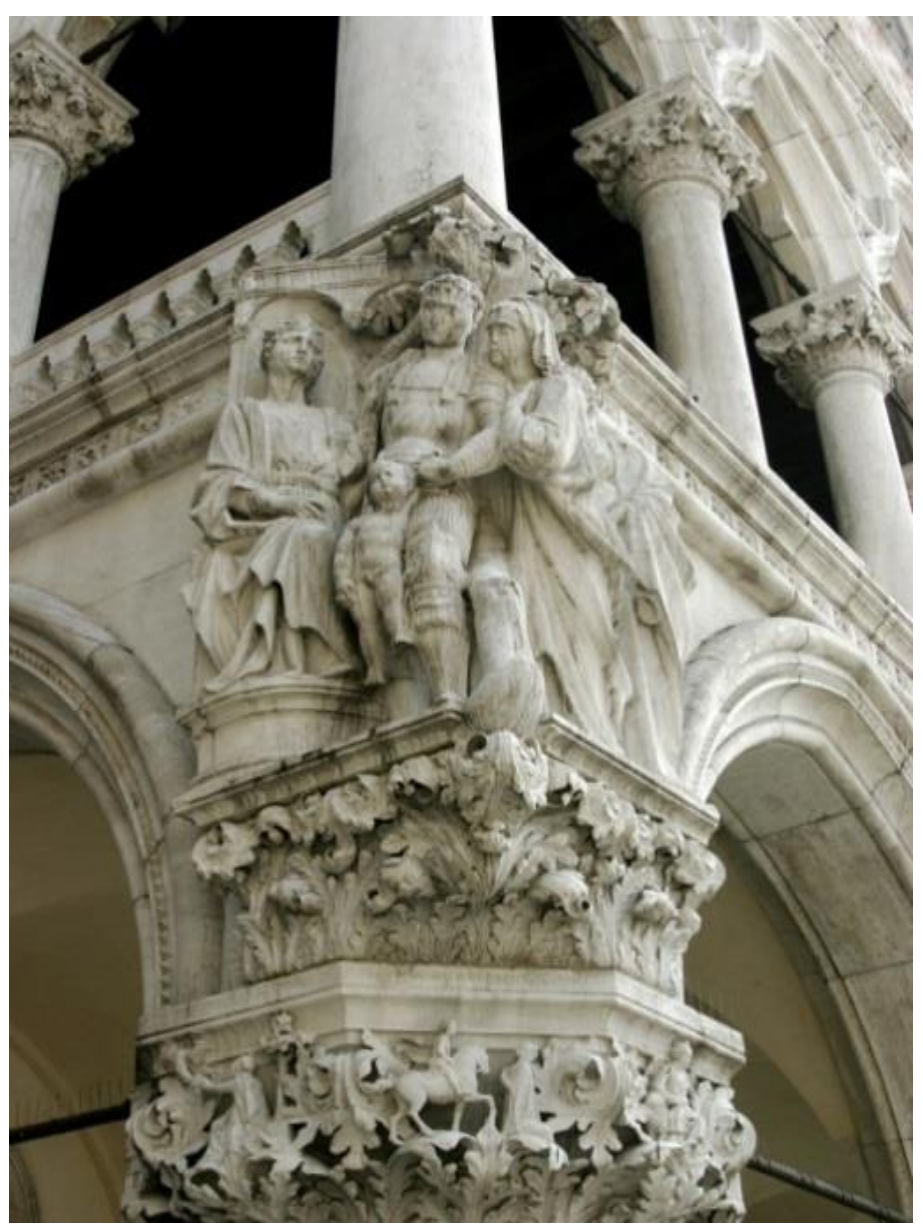

Kettejük közül nyilvánvalóan az volt az ártatlan, aki a csecsemő megkíméléséért fellebbezett, és az volt a tettes, aki nem sajnálta a másik gyerekét, hanem úgy vélte, igazságos, hogy egyiküké se legyen. Salamon ezek után az igazi anyának ítélte meg a gyereket. Mint bíró, egy olyan ügyben, ahol nem voltak tanúk, a per során a „kinek az érdeke?” kérdésre kereste a választ, és a belső indíték kiderítésével tett igazságot. Aki megirigyelte a más gyermekét, az is leleplezte magát beszédével, és az ártatlanul megvádolt asszonyról is kiderült az igazság abból, ahogy reagált. Salamon precedenst teremtő döntése bevonult az európai jogi köztudatba, és az ítélethozatal mércéjét magasra állította, az indítékok feltárásában mély emberismeretről téve tanúságot.

6. kép: Salamon döntése. Velence, dózsepalota

\section{Az ítélőszék régen és ma}

A jogalkalmazók és jogértelmezők felelőssége a törvény eredeti célját szem előtt tartani: vajon az ítélettel okozott esetleges kár mértéke nem haladja-e meg a megítélt cselekedettel okozott erkölcsi vagy anyagi kárt? A törvényesség és az igazságosság időnként elválhat egymástól. Egy ízben arról elmélkedik egy bibliai szerző, vajon a legfőbb Bíró egyetért ilyenkor az ítélettel? „V an-é köz̨e te hozzád a hamisság székének, amely nyomorúságot szerez, törvény szine alatt?’80 - teszi fel a kérdést. Másutt megállapítja, hogy a bíróval maga Isten volt: „véghezvitted itéletemet és ügyemet: az, itélöszé́kben ültél, mint igaz biró." 81

A bíróságok üléstermeinek berendezése hagyományosan egy tekintélyt parancsoló emelvényt is magában foglal. A bírói szék már az antikvitásban az ítélethozatal helye volt, amin a bíróság előtt vitázó felek álltak. A görögül bémá-nak, héberül bimá-nak nevezett emelvény Pál apostol perében a római joghatóság jelképe, ahol a császárhoz fellebbezett. ${ }^{82}$ Az Újszövetség a végső itélet helyét is ítélőszéknek nevezi. ${ }^{83} \mathrm{Az}$ igazságszolgáltatás malmai régen is lassan őröltek.

\footnotetext{
80 Zsoltárok 94:20

${ }^{81}$ Zsoltárok 9:5

82 Apostolok cselekedetei 25:10

${ }^{83}$ Róma 14:10
} 
Jézus egy példázata összehasonlít egy hanyag bírót az igazságos Istennel, akihez panaszukkal fordulnak.

„Volt egy bíró egy városban, aki Istent nem félt és embert nem becsült. Volt pedig abban a városban egy özvegyasszony, és elméne abhoz, mondván: Állj bosszút értem az én ellenségemen. Azpedig nem akará egy ideig; de azután monda ö magában: Jól lehet Istent nem félek és embert nem becsülök; Mindaحáltal mivelhogy nékem terhemre van ez az özvegyasszony, megszabaditom öt, hogy szüntelen reám járván, ne gyötörjön engem. Monda pedig az. Úr: Halljatok, mit mond e bamis biró! Hát az Isten nem áll-é bosszút az ő válasz̨tottaiért, kike ö hozzá kiáltanak éjjel és nappal, ha hosszútürö is irántuk?’"84

Ezzel visszajutottunk kiindulásunkhoz, a Tízparancsolat két kőtáblájához. A hamis bíró egyiket sem tartotta fontosnak: Istent nem félte és az embereket nem becsülte. Ebből a példázatból levezethető, hogy az igaz bíró nyilvánvalóan ellenkezőleg fog tenni, figyelembe veszi mind vertikális, mind a horizontális irányú kötelességét, és nem csak akkor szolgáltat igazságot, ha rájárnak és gyötrik. A történet tanulsága, hogy a lassú ügyintézés is jobb, mintha egyáltalán nem lenne ítélethozatal.

\section{Néhány gondolat a Törvény újszövetségi értelmezése kapcsán 6.1. A názáreti Jézus és a Tóra}

„Akkor hozzá menvén egy az irástudók közül, aki az ö vetekedésöket hallotta vala, és tudván, hogy jól megfelele nékik, megkérdezé töle: Melyik az, elsö minden parancsolatok köröött? Jézus pedig felele néki: Minden parancsolatok között az elsö: Halljad I rráel: Az Úr, a mi Istenünk egy Úr. Szeressed azért az Urat, a te Istenedet teljes szivedböl, teljes lelkedböl, és teljes elmédböl és teljes erödböl. E₹ az elsố parancsolat. A második pedig hasonlatos ebhe₹: Szeresd felebarátodat, mint magadat. Nincs más ezeknél nagyobb parancsolat." 85 A Törvény lényege Jézus szerint Istennek és a felebarátainknak a szeretete.

Az újszövetség a fent idézett két kőtáblát, azaz a Tízparancsolatot két alapvető kijelentésre vezeti vissza, melyek a Tórában vannak, és amelyek lényegét képezik mindezen parancsolatoknak. A názáreti Jézrus törvénytisztelő zsidóként a Tóra betüjét is fontosnak tartotta. ${ }^{86} \mathrm{~A}$ törvényben foglaltakat lényegesebbnek ítélte, mint az ahhoz füzött szóbeli magyarázatot. A jószándékú, de kibírhatatlan emberi rendeleteket élesen bírálta, akár kiskaput jelentettek a törvény eredeti intenciójához képest, mint például a szülők segítésére fordítható pénz templomi ajándékul adása, ${ }^{87}$ vagy épp szigorítást jelentettek, mint a szombaton leszedett pár kalász megevését is munkának minősítő törvényértelmezés. Az első esetben a szülők tiszteletét fontosabbnak tartotta, mint a fogadalmi ajándék adását, a törvény életet támogató rendeltetését tartva szem előtt. A teremtés logikáját látta meg a törvényben, hangsúlyozva, hogy a szombat lett az emberért, és nem fordítva. 88 Szívesen idézte Hóseás prófétát, aki kijelentette, a Törvényadó eredeti szándéka az irgalmasság, és nem az áldozat. ${ }^{8}$

\footnotetext{
${ }^{84}$ Lukács 18:1-7

${ }^{85}$ Márk 12:28-31; vö. Róma 13:8-10; Jakab 2:8-9

${ }^{86}$ Máté 5:17-18

87 Máté 15:1-6

${ }^{88}$ Márk 2:27

${ }^{89}$ Az evangéliumban Jézus Hóseás 6:6-ot háromszor idézi. Máté 9:13-ban és 12:7-ben, a 23:23-ban pedig az ítélet szükségessége mellett utal az irgalmasságra. A görög eleosz̧ a héber chesz̧ed megfelelője, jelentése irgalmasság, szeretet.
} 


\subsection{A kereszténység kezdetei és a Törvény}

A jeruzsálemi ősegyház írásmagyarázatát nem a legalizmus, hanem a messianizmus jellemezte. ${ }^{90} \mathrm{Az}$ első jeruzsálemi zsinat foglalkozott azzal, hogy a nemzetekből származó keresztények mit tartsanak be törvényből. Döntésükben a Noéval kötött szövetségben megfogalmazottakra szorítkoztak, amelyek a nemzetekre vonatkoznak: a monoteizmust és a monogám házasságot követelték meg köreikben. A Tízparancsolatban foglalt egyetemes erkölcsi elvek mellett a ceremoniális törvények közül csak a közegészségügyre tartozó dögevést tiltották, és a vérrel kapcsolatos rendelkezésre emlékeztették őket: „tartózkodjatok a bálványoknak áldozott dolgoktól, a vértöl, a fúlva holt állattól, és a paráznaságtól; melyektöll ha megóvjátok magatokat, jól lesz dolootok." 91 A zsidó ünnepek megtartásában szombat és a vasárnap ünneplésében párhuzamosság figyelhető meg az újszövetségi keresztény gyülekezetekben, melyek többnyire a helyi zsinagógából nőttek ki. A vasárnap tartalma eltért a szombattól, nem a pihenés, hanem a közösségápolás, tanítás volt a célja és mindenekelőtt Jézus feltámadásának ünneplése. ${ }^{92} \mathrm{Az}$ Ószövetség recepciója az Újszövetségen keresztült történt meg az európai nemzetekben és hatotta át a nyugati civilizációt. Ez azt jelenti, hogy mózesi Törvényből csak annyit vettek át, amennyit az apostolok követendőnek tartottak. Jézus Krisztus követői a mózesi törvényt annak univerzális erkölcsi küldetésében ragadták meg és terjesztették.

\subsection{A törvény és az evangélium}

„Ám a törvény szent, és a parancsolat szent és igaz és jó."93 Szent Pál, a nemzetek apostola írásaiban rendszeresen foglalkozik a bűn, a törvény és az igazság problematikájával. Jelen írásban csak a jogrend szempontjából legfontosabbra szorítkozva, ez nézete úgy összegezhető, hogy a jó nincs a törvénynek alávetve, hanem a törvény fölött áll. Remélte, hogy az evangélium hirdetése következtében nagy tömegekben válhat a törvény benső iránytűvé, és olyan életmódban ölt testet, ami semmilyen törvénnyel nem ütközik. „Tudjuk pedig, hogy a törvény jó, ha valaki törvényszerúen él vele, tudván ą̧, hogy a törvény nem az igazért van, hanem a törvénytaposókért és engedetlenekért, az istentelenekért és bünösökért, a latrokért és fertelmesekért, az atya- és anyagyilkosokért, emberölökért. Paráznákért, férfifertöztetókért, emberrablókért, hazugokért, hamisan eskïvökért, és ami egyéb csak az egészséges tudománynyal ellenkęik, a boldog Isten dicsöségének evangéliuma szerint, mely reám bizatott."94

Pál apostol - a már említett ítélőszék előtt állva - Porcius Festus előtti védőbeszédében meggyőződéssel vallotta, hogy a próféták munkássága az evangéliumon keresztül felvilágosítja a nemzeteket. „De Istentöl segítséget vévén, mind e mai napig állok, bironyságot tévén mind kicsinynek, mind nagynak, semmit sem mondván azokon kivül, amikeôl mind a próféták. megmondották, mind Móres, hogy be fognak teljesedni: Hogy a Krisztusnak szenvedni kell, hogy mint a balottak. feltámadásából elsó, világosságot fog birdetni e népnek és a pogányoknak."

A nemzetek és a Tóra viszonyát abban látta, hogy a törvény Isten ajándéka Izraelnek, és a

\footnotetext{
${ }^{90}$ Legjobb példa erre Simon Péter három nyilvános beszéde az Apostolok cselekedeteinek 2-4. részében.

91 Apostolok cselekedetei 15:29

${ }^{92}$ Apostolok cselekedetei 20:7; Róma 14:6

${ }^{93}$ Róma 7:12

941 Timoteus 1:8-11
} 
bűn megismerésére való. A törvény és a prófétai írások célja elvezetni minden embert a Messiáshoz, aki a belé vetett hit által igazzá tudja tenni a bủnöst: „Mivelhogy egy az. Isten, aki megigarítja a zsidót hitböl és a pogányt hit által." 95 Izrael küldetése a nemzeteket felvilágosítani, ezt a küldetését maga részéről az evangélium terjesztésével töltötte be.

\subsection{Az Újszövetség és az államhatalom}

A Római Birodalom vagy akár barbár királyságok alattvalójaként a keresztények és zsidók ugyanúgy a polgári közigazgatás alá tartoztak, mint a görög, római vagy más vallású emberek. Az Újszövetség tudomásul veszi az állami felsőbbséget, és a hatóságoknak való engedelmességet hirdeti, amíg az nem ütközik Isten parancsaiba. ${ }^{96}$

Pál apostol a Rómaiakhoz írt levél 13. részében rakta le a keresztény államelmélet alapjait. A szolgáló hatalom fogalmát ennek az alapvetésnek köszönhetjük. „Minden lélek engedelmeskedjék a felsö hatalmasságoknak; mert nincsen hatalmasság, hanem csak Istentöl: és amely hatalmasságok vannak, az, Istentöl rendeltettek. Azért, aki ellene támad a hatalmasságnak, az. Isten rendelésének támad ellene; akik pedig ellene támadnak, önmagoknak itéletet szereznek. Mert a fejedelmek nem a jó, hanem a rossz cselekedetnek rettegésére vannak. Akarod-é pedig, hogy ne félj a hatalmasságtól? Cselekedjed a jót, és dícséreted lesz attól. Mert Isten szolgája ö a te javadra. Ha pedig a gonosz̨t cselekszed, félj: mert nem ok nélkül viseli a fegyvert: mert Isten szolgája, bosszuálló a haragra annak, aki gonoszt cselekszilk." 97

A fenti szakasz rávilágít az Isten szuverenitásából levezetett állami szuverenitás fogalmára. Az Isten által az államra ruházott hatalom nem autonóm, hanem delegált hatalom, aminek erkölcsi küldetése van. Feladata, hogy üldözze a bűnt és jutalmazza a jót, azaz: a törvényszegőoön bosszút álljon, de a törvénytisztelők félelem nélkül élhessenek.

Ha fordítva történik, akkor „nem beszélhetünk arról, hogy azérintett vezetöt vagy rezsimet valamiféle isteni végzés emelte pozícióba, vagy tartaná ott. Fontos különbséget tenni tehát az. Istentöl eredö hatalmi jogkör és annak betöltöje között. A Biblia sžerint fontos, hogy legyen hatalmi/ tekintélyi rend, mert különben anarchia lenne, beköszöntene a lelkiismereti korszakot meghatározó <ember embernek farkasa> állapot, ugyanakkor elitélendó, ha a hatalommal visszaélnek, mert a <fejedelmek, nem a jó, hanem a rossz, cselekedetnek, rettegésére vannak.>"98 A nemzetek és birodalmak jogrendjét az Újszövetség nem tekinti szakrálisnak, hanem olyannak, ami javításra, humanizálásra szorul, hogy a hatalom mindinkább a közjót szolgálja.

\section{7. Összefoglalás}

A Biblia, azon belül a Tóra a zsidóság és a kereszténység közös kultúrkincse. Számos jogelv, amely formálta a nyugati civilizációt, a mózesi Törvényben gyökerezik. Ezeket a kereszténység is becsben tartotta, és a szabadságjogok irányába továbbfejlesztette. Ezen elvek: az emberi méltóság minden egyént megillető tisztelete, az emberi élet értéke és védelme, a család és a magántulajdon védelme, a jó hírnévhez fűződő jog, a privátszféra tisztelete. A jog területén a független bíróság, az igazságos

\footnotetext{
${ }^{95}$ Róma 3:30

${ }^{96}$ Róma 13:1-3; Apostolok cselekedetei 5:29

${ }^{97}$ Róma 13:1-4

${ }^{98}$ MÉSZÁROS, Bibliai államelmélet 4.
} 
és pártatlan eljárás, a törvényes rend és közbiztonság fogalmát, a hatalmi ágak elválasztásának és a jogállamnak az eszményét köszönhetjük a máig releváns tórai elveknek.

\section{Felhasznált források és irodalom}

AugustinE: Writings Against the Manicheans. The two souls. Christian Classics Ethereal Library. http://www.ccel.org/ccel/schaff/npnf104.iv.vi.xv.html (letöltés: 2017. 10. 04.)

BEN-SAsson, H. H. et al. (szerk.): A History of the Jewish People. Cambridge - Massachusetts 1976

Biblia Hebraica StUTTGarTensia. Stuttgart 1984

CONNER, K. Jr.: The Foundation of Christian Doctrine. Chichester 1988

GeSenius’ Hebrew and Chaldee LeXicon to the Old Testament SCRIPTURes. Michigan 1994 (reprint, 1. kiadás: 1857)

HAMMURABI törvényei (ford. KMOSKÓ Mihály). Kolozsvár 1911 http://mek.niif.hu/07200/07287/07287.pdf

(letöltés: 2017. 10. 01.)

JOHNSON, Paul: A zsidók története. Budapest 2005

MCMILLAN, S. I. (MD): Elekerülhető betegségek. Ellenségeskedés vagy szeretet, stress vagy békesség. Egy orvos érvelései a Biblia jelenlétében. Bissingen é. n.

MÉSZÁros István: Bibliai államelmélet. Budapest 2007

MizRAHI, M. Maurice: Justice. Torah Discussion on Shofetim, Springfield 2006

http://images.shulcloud.com/618/uploads/PDFs/Divrei_Torah/justice.pdf (letöltés: 2017. 10. 04.)

NOVUM TESTAMENTUM GRAECE. Stuttgart 1983

SENECA: Medea. Edited with Introduction, Translation, E-Commentary by A. J. BoYLE, Oxford 2014

SZENT BiBLIA (ford. KÁROLI Gáspár). Budapest 2004 